\title{
Process Parameters of Production of Non-Autoclaved Aerated Concrete on the Basis of Complex Use of Ash and Gypsum-Containing Wastes
}

\author{
Aruova Lyazat - Dr.Professor \\ University named after Korkyt Ata, Kyzylorda 120008, 29, Khan st, \\ ecoeducation@mail.ru
}

\section{Dauzhanov Nabi - Candidate of Technical Sciences}

University named after Korkyt Ata, Kysylorda

\section{Doi:10.5901/mjss.2014.v5n23p2565}

\section{Abstract}

\begin{abstract}
Aerated concretes belong to the most effective materials for fencing structures of buildings of different purpose. They are characterized by their quite high strength and freeze resistance though they have comparatively low average density. More and more perspectives for their further production and appliance in construction is created by their high technical and economical indications of production and appliance of aerated concrete products, fire safety, as well as comfortable living conditions inside houses with aerated concrete walls because of their high air and vapor transmission. Aerated concrete of non-autoclaved hardening on physical and mechanical properties, close to properties of autoclaved aerated concrete ( $D<600, M>35, F>50)$, is intended to be produced by mechano-chemical activation of raw components, optimization of quality of aerated concrete macroporous structure and complex use of production as well as fuel and power complex wastes.
\end{abstract}

Keywords. Aerated concrete, foam concrete, binding, ash, gypsum, non-autoclaved, autoclaved, wastes

\section{Introduction}

Aerated concretes belong to the most effective materials for fencing structures of buildings of different purpose. They are characterized by their quite high strength and freeze resistance though they have comparatively low average density.

More and more perspectives for their further production and appliance in construction is created by their high technical and economical indications of production and appliance of aerated concrete products, fire safety, as well as comfortable living conditions inside houses with aerated concrete walls because of their high air and vapor transmission.

Main conditions, that provides competitive ability of aerated concrete under current conditions and further increase of production of its products are as follows:

- reducing of power and material intensity during production of aerated concrete products in case of provision with high indicators of physical and mechanical concrete properties;

- increasing of aerated concrete thermal properties in order to increase premises' comfort and reduce power consumption for buildings heat supply system.

Aerated concrete of non-autoclaved hardening on physical and mechanical properties, close to properties of autoclaved aerated concrete $(D<600, M>35, F>50)$, is intended to be produced by mechano-chemical activation of raw components, optimization of quality of aerated concrete macroporous structure and complex use of production as well as fuel and power complex wastes.

All abovementioned determines actuality, scientific and practical significance of real researches. There are developed optimal compositions of ash-gypsum-concrete-binding materials on the basis of complex use of ash and different gypsum-containing wastes; results of researches on main construction and technical properties of ash-gypsumconcrete-binding materials; developed tailored compositions of non-autoclaved gas and foam concrete on the basis of ash-gypsum-concrete-binding materials, as well as on the basis of the same unground raw components; results of researches of influence of process factors on properties of concrete mixtures and aerated concrete; study results of hydration and hardening peculiarities of aerated concrete on the ash-gypsum-concrete-binding materials basis; results of influence of process factors on quality of macroporous structure; results of determination of main physics and mechanical properties and field of its appliance; results of experimental implementation of non-autoclaved aerated concrete products. 
There is theoretical justification and experimental prove of possibility of producing of low-clinkered hydraulic ashgypsum-concrete-binding materials of different brands and on the basis of ash and gypsum-containing component which is made mainly of calcium sulfate dehydrate and non-autoclaved aerated concrete on its basis on physical and mechanical properties which are close to autoclaved aerated concrete. Theoretical and experimental basics for formation of qualitative macroporous structure of non-autoclaved aerated gypsum and ash concrete are developed. Practical importance of work is development of energy-saving technology for production of non-autoclaved aerated concretes, which, according to their physical and mechanical properties, are close to properties of autoclaved aerated concrete on the basis of complex use of ash and different gypsum-containing wastes, which are recommended for use for production of small size wall blocks.

According to results of work the relevant process regulations was developed for production of Ash-GypsumConcrete-Binding materials and high-strength non-autoclaved aerated concrete on its basis. Research results passed factory testing.

Experimental-industrial batch of small size wall blocks made of non-autoclaved aerated concrete on the basis of ash, gypsum-containing component and portland cement was manufactured at experimental shop of Stroyindustriya M LLP, Zheleznodorozhny city, Moscow oblast. At that it was established that produced small size wall blocks satisfy requirements of GOST 25485-89 and GOST 21520-89 with respect to main physical and mechanical properties.

After carrying out of experimental modelling, results obtained in laboratory conditions were completely proved and possibility and practicability of production of aerated concrete on the basis of abovementioned raw components was established.

\section{Materials and Methods}

The author, in his researches, was governed by industrial wastes peculiarities, developments in field of technology of binding and aerated concrete on its basis which allows improving construction material's properties which was reflected in work of CIS scientists. It was clear from literature review that researches on development of non-autoclaved aerated concrete on the basis of ash, gypsum, portland cement had been carried out earlier. Herewith it was also established that during these researches final product (construction gypsum, anhydrite etc.) was applied as gypsum-containing component.

Such industrial wastes as gas purification products, as well as natural gypsum raw products and phosphogypsum, that consists mainly of calcium sulfate dihydrate were applied as gypsum-containing component as part of binding composition in these researches.

Reason for using of calcium sulfate dihydrate as main initial component in binding material instead of calcium sulfate hemihydrate was the fact that during use of calcium sulfate hemihydrate it very quickly hydrated to dihydrate one, and it was in this form during hardening processes.

Economically, use of dihydrate gypsum instead of calcium sulfate hemihydrate has the same advantages as exclusion of consumption for calcination of row gypsum, reducing of normal consistence of cement paste (up to $24-27 \%$ against $50-60 \%$ if calcium sulfate hemihydrate is used), that allows to increase products strength without increasing portland cement clinker consumption.

On the basis of published researches, as well as results of physical and chemical properties of wastes, possibility and practicability of complex use of ash and gypsum-containing wastes for production of aerated concrete of nonautoclaved hardening was found out.

In order to carry out experimental researches, the following raw materials were used: portland cement of Makhaylovsliy and Voskresenskiy plants, fly ash of Rayzan Thermal Power Plant, natural gypsum of New-Moscow field, phosphogypsum of Voskresenskiy chemical plant.

Portland cement of Makhaylovsliy plant has the following mineral composition: $\% C_{3} S-61 ; C_{2} S-13 ; C_{3} A-9 ; C_{4} A F$ $-12$. $\mathrm{C}_{4} \mathrm{AF}-14$

Portland cement of Voskresenskiy plant has the following mineral composition: $\% C_{3} S-59 ; C_{2} S-12 ; C_{3} A-7$;

Fly ash of Rayzan Thermal Power Plant belongs to acid ash and has the following chemical composition: $\% \mathrm{SiO}_{2}$ 50,39; $\mathrm{Al}_{2} \mathrm{O}_{3}-33,26 ; \mathrm{Fe}_{2} \mathrm{O}_{3}-5,9 ; \mathrm{CaO}$ - 7,24; $\mathrm{MgO}$ - 1,26; $\mathrm{K}_{2} \mathrm{O}$ - 0,52; $\mathrm{Na}_{2} \mathrm{O}$ - 0,15; ignition losses- 1,1.

Its dispersiveness is equal to $2830 \mathrm{~cm}^{2} / \mathrm{g}$, argillo-ferruginous module, represented by ratio of sum of aluminum and ferrum oxides to silicon oxide, is equal to 0,77 .

Due to current absence of industrial gas purification product the simulation of its composition production was carried out. Laboratory reagent $\mathrm{CaSO}_{4} 2 \mathrm{H}_{2} \mathrm{O}$ and natural gypsum rock, which was subject to grinding up to specific 
surface of $2500 \mathrm{~cm}^{2} / \mathrm{g}$ were used for research because gas purification product is mainly composed of calcium sulfate dihydrate.

Phosphogypsum is composed of calcium sulfate dehydrate, which represents granular damp powder with humidity of $16-20 \%$ and has the following chemical composition: \% $\mathrm{CaO}-30,32 ; \mathrm{SO}_{3}-45,95 ; \mathrm{SiO}_{2}-0,74 ; \mathrm{Fe}_{2} \mathrm{O}_{3}-0,18 ; \mathrm{Al}_{2} \mathrm{O}_{3}$ 0,$56 ; \mathrm{MgO}-0,1 ; \mathrm{K}_{2} \mathrm{O}-0,1 ; \mathrm{Na}_{2} \mathrm{O}-0,13 ; \mathrm{P}_{2} \mathrm{O}_{5}-0,75$; ignition losses - 11,26.

Aluminum powder ПАП-1, which corresponds to GOST 5494-71 was used in the laboratory experiments as gasforming agent.

Synthetic porophore was used in the researches as foaming agent. Physical and mechanical properties of AshGypsum-Concrete-Binding Materials and aerated concrete were determined according to relevant methods of normative documents.

Study of macroporous structure of aerated concrete was carried out at photoelectronic unit.

Selection of optimal proportion between components of binding and aerated concrete raw mixture was carried out with use of experiments planning mathematical methods.

During proportioning of Ash-Gypsum-Concrete-Binding Materials compositions, the studied process factors were $C$ (proportion between ash and binding material) and concentration of gypsum in binding material, and optimization parameters - Water-to-Cement ratio, setting time, strength and water resistance.

\section{Results}

As the result of researches influence of gypsum-containing component type on basic properties and production process of Ash-Gypsum-Concrete-Binding materials was studied.

It was established that in case of application of both natural gypsum and reagent-grade gypsum simulating gas purification product as well as phosphogypsum as sulfate -containing component we could observe clearly expressed optimums of proportion between ash and binding $(C)$ which are accordingly equal to $0,42,0,6$ and 0,5 , which were used during proportioning of optimal compositions of Ash-Gypsum-Concrete-Binding materials.

Testing of samples of different composition, made of standard consistency paste, which were hardened after steam treatment in different conditions: in the air, water, above water, had showed that increasing of its strength was equal to $150-250 \%$ and it depended on composition of fine powdered binding material. Samples that hardened in water have the most strength increasing in comparison with samples that hardened above water or in the air.

Characteristic curve of water-resistance coefficient of Ash-Gypsum-Concrete-Binding Materials samples of different composition out of $C$ and concentration of gypsum in binding material (\%), is presented at the picture.1., where points of factor space are connected with continuous line and characterized by the same water-resistance coefficient values.

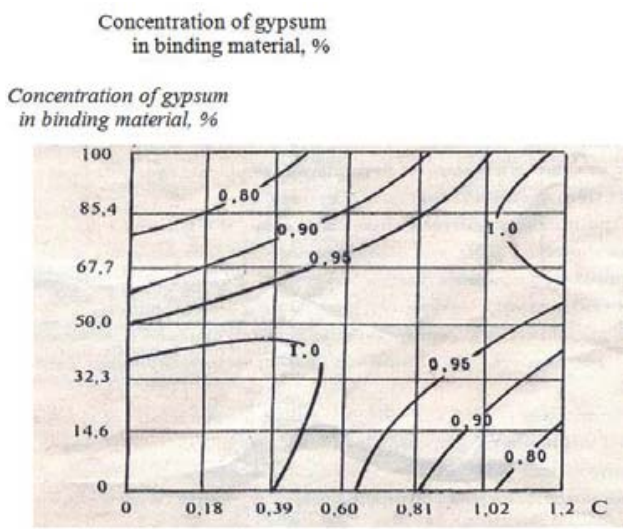

Picture 1. Dependence of coefficient of water-resistance of cement rock if it is kept in water out of ash/binding proportion (C) and concentration of gypsum in binding material (\%).

All these compositions are characterized as having quite high water-resistance. Samples of concrete rock prepared on the basis of Ash-Gypsum-Concrete-Binding materials with high concentration of gypsum (over 50\%) and low ash 
concentration, are characterized as having comparatively low water-resistance. Samples, made of Ash-GypsumConcrete-Binding materials with high concentration of ash has tendency to reduction of water-resistance. There are optimal compositions of Ash-Gypsum-Concrete-Binding materials in the Table No.1.

Table 1. Influence of sulfate-containing component type on strength, water resistance and setting time of Ash-GypsumConcrete-Binding materials.

\begin{tabular}{|c|c|c|c|c|c|c|c|}
\hline \multirow[t]{2}{*}{$\begin{array}{c}\text { Type of sulfate-containing } \\
\text { component }\end{array}$} & \multicolumn{3}{|c|}{ Composition characteristics, $\%$} & \multirow{2}{*}{$\begin{array}{l}\text { Strength } \\
\text { of concrete rock, } \\
\mathrm{kgf} / \mathrm{cm} 2\end{array}$} & \multirow[t]{2}{*}{$\begin{array}{l}\text { Water-resistance } \\
\text { coefficient }\end{array}$} & \multicolumn{2}{|c|}{$\begin{array}{l}\text { Setting time, } \\
\min \end{array}$} \\
\hline & $\begin{array}{c}\text { Sulfate-containing } \\
\text { component }\end{array}$ & Concrete & Ash & & & start & duration \\
\hline Natural gypsum & $\begin{array}{l}60 \\
50 \\
40 \\
30\end{array}$ & $\begin{array}{l}10 \\
20 \\
30 \\
40\end{array}$ & \begin{tabular}{l|}
30 \\
30 \\
30 \\
30 \\
\end{tabular} & $\begin{array}{l}100 \\
200 \\
300 \\
400 \\
\end{array}$ & $\begin{array}{l}0,85 \\
0,92 \\
0,96 \\
1,00\end{array}$ & $\begin{array}{l}330 \\
315 \\
300 \\
300 \\
\end{array}$ & $\begin{array}{l}220 \\
180 \\
150 \\
150\end{array}$ \\
\hline Chemically pure gypsum & $\begin{array}{l}65 \\
57 \\
48 \\
38 \\
30 \\
23 \\
\end{array}$ & $\begin{array}{l}- \\
92 \\
18 \\
28 \\
36 \\
43 \\
\end{array}$ & \begin{tabular}{|l|}
35 \\
34 \\
34 \\
34 \\
34 \\
34 \\
\end{tabular} & $\begin{array}{l}100 \\
200 \\
300 \\
400 \\
500 \\
600 \\
\end{array}$ & $\begin{array}{l}- \\
- \\
- \\
- \\
- \\
-\end{array}$ & $\begin{array}{l}320 \\
300 \\
280 \\
255 \\
240 \\
225 \\
\end{array}$ & $\begin{array}{c}720 \\
420 \\
300 \\
150 \\
90 \\
90 \\
\end{array}$ \\
\hline Phosphogypsum & $\begin{array}{l}58 \\
48 \\
40 \\
32 \\
20\end{array}$ & $\begin{array}{c}7 \\
14 \\
22 \\
30 \\
42\end{array}$ & \begin{tabular}{|l|}
38 \\
38 \\
38 \\
38 \\
38 \\
\end{tabular} & $\begin{array}{l}200 \\
300 \\
400 \\
500 \\
600\end{array}$ & $\begin{array}{l} \\
- \\
- \\
-\end{array}$ & $\begin{array}{l}20 \\
10 \\
10 \\
15 \\
65\end{array}$ & $\begin{array}{c}40 \\
60 \\
80 \\
100 \\
122\end{array}$ \\
\hline
\end{tabular}

Whereas gas purification product together with dihydrate may contain calcium hemihydrate Ash-Gypsum-ConcreteBinding Materials properties depending on proportion of hemihydrate and dihydrate as components of sulfate-containing component were studied. Strength of Ash-Gypsum-Concrete-Binding materials changes ambiguously and have complicated regularity: if there is partial replacement of dihydrate with hemihydrate up to 30 , and sometimes to $50 \%$, it grows and then reduces during simultaneous reducing of water-resistance coefficient. This regularity is a result of quick hydration of hemihydrate (construction gypsum) i.e. increasing of share of quick hydrated component in composition of binding material and making its properties close to gypsum- pozzolanic binding material with relevant for this binding material sequence of passing of physical and chemical hydration processes.

It is established that basic criteria, that determines construction and technical properties of Ash-Gypsum-ConcreteBinding materials, is proportion between dihydrate and hemihydrate modifications of calcium sulfate in sulfate-containing component. Optimal concentration of calcium sulfate dihydrate as composition part of gypsum-containing component for production of Ash-Gypsum-Concrete-Binding materials with normal setting time shall be no more than $50 \%$ in weight.

The next and main purpose of thesis work was development of optimal composition and process parameters of non-autoclaved aerated concrete production, on the basis of Ash-Gypsum-Concrete-Binding materials, which provides production of aerated concrete with maximum strength and freeze-resistance.

Grinded natural gypsum was used as gypsum-containing component at first stage of research on development of optimal compositions of aerated concrete.

Water-Solids Ratio and proportion between ash and binding material (C) was accepted as variable processing factor with the purpose of determination of minimal consumption of binding material if tailored aerated concrete properties are provided.

The following was accepted as optimization parameters: fluidity, average density, compressive strength, portland cement consumption.

As the result of statistic processing of experiment data, qualitative dependences of main properties of concrete mixture and aerated concrete on studied process factors were found out. On the basis of obtained dependences analysis optimal compositions of aerated concrete were determined.

On the basis of abovementioned researches results and with purpose of maximum increase of physical and mechanical properties of produced aerated concrete, optimization of its porous structure was carried out.

Second order rotatable design for three variables was implemented for this purpose. 
The following was accepted as variable processing factors: for aerated concrete - Water-Solids Ratio, temperature of aerated concrete mixture and consumption of aluminum powder, and for foam concrete - foam and concrete mixing time, Water-Solids Ratio and also consumption of foaming agent.

Fine powdered mixture was used as binding material, produced by joint grinding of ash (40\%), gypsum-containing component (30\%) and portland cement (30\%). Optimal proportion between ash and binding material (C), as well as established one as the result of work on previous stage, was equal to 0,74 and accepted as permanent in all experiments.

Characteristic curve of main properties of gas and foam concrete from studied processing factors (picture 2 and 3 ) was obtained after statistic processing of experiment results.

On the basis of obtained dependences analysis, optimal compositions of aerated and foam concrete were determined. The results specified on the picture 2 shows, that produced non-autoclaved aerated concrete on the basis of Ash-Gypsum-Concrete-Binding materials is characterized with average density from 800 to $1100 \mathrm{~kg} / \mathrm{m}^{3}$ and strength, accordingly from 50 to $100 \mathrm{kgf} / \mathrm{cm} 2$. Non-autoclaved foam concrete (picture 3) is characterizes as having more wide range of density (from 400 to $1200 \mathrm{~kg} / \mathrm{m}^{3}$ ) and strength (from 10 to $100 \mathrm{kgf} / \mathrm{cm}^{2}$ ).

Herewith it is established that foam concrete of optimal composition if density for example is $800 \mathrm{~kg} / \mathrm{m}^{3}$ dominates similar aerated concrete indicators with respect to strength indications by $15-20 \%$.

Researches of macroporous structure of these concretes, which were carried out at photoelectronic unit, have shown, that not size or shape of pores has the most influence on strength of aerated concrete, but uniformity of its distribution according to volume of concrete, which is quantitatively evaluated by porosity dispersion.
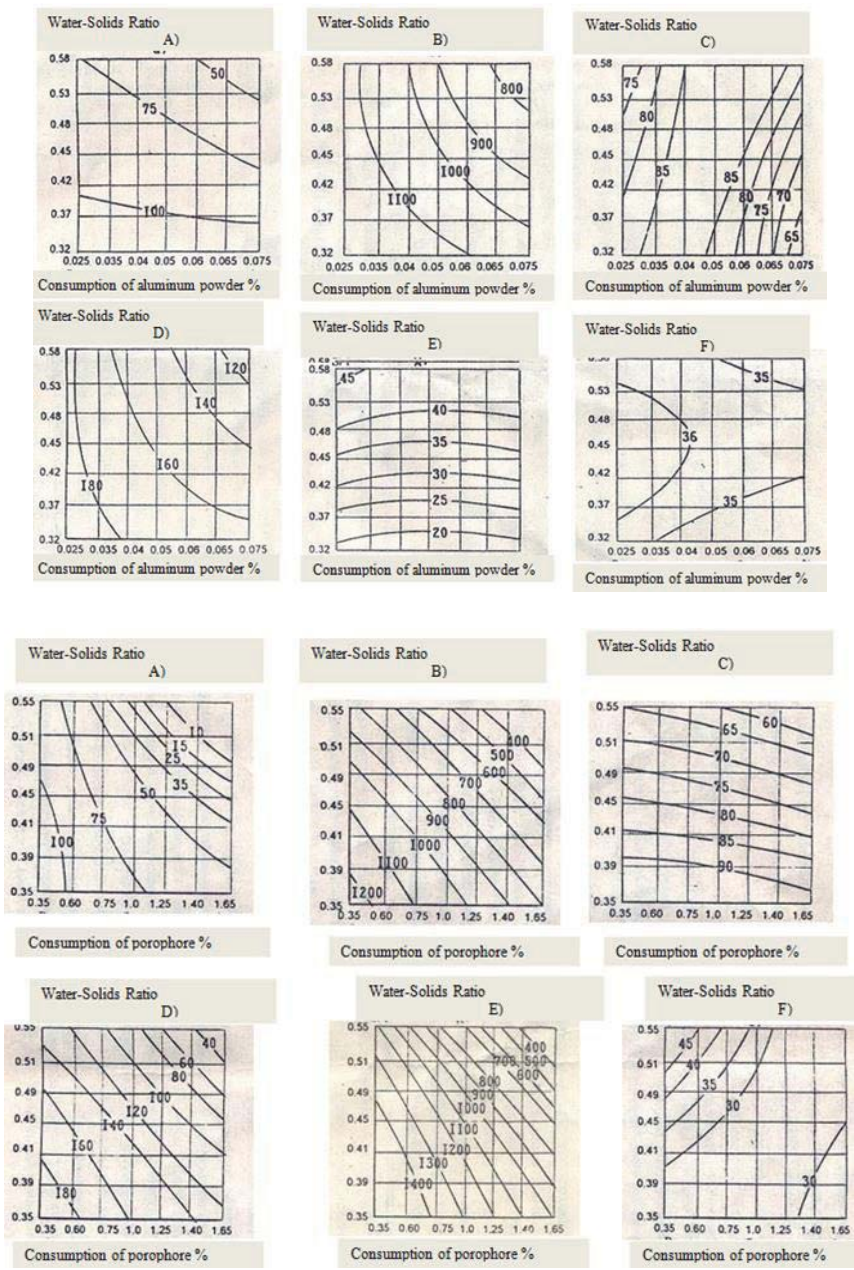
Coefficient of variation of quality indicator of aerated concrete macroporous structure $(v=19,3 \%)$ in comparison with foam concrete $(v=13,6 \%)$ that was established by researches, demonstrates that aerated concrete has more non-uniform structure that is result of comparatively low indications of its strength (if density is the same)

According to strength indications, produced non-autoclaved concrete are very closed to strength indications required by GOST 25485-89 to autoclaved aerated concrete.

Study kinetics of plastic strength increasing of aerated concrete has shown that plastic strength of row aerated concrete of optimal composition is $100-150 \mathrm{kgf} / \mathrm{cm}^{2}$ after two hours after production, which is optimal for cutting of aerated concrete mass into small-sized blocks. Growth of plastic strength is observed during reduction of water-solid ratio and if relevant $\mathrm{C}$ is increased, i.e. ash concentration.

\section{Discussions}

Foam concrete in studied field is characterized as having more slow speed of plastic strength increasing, than aerated concrete. Herewith plastic strength of row foam concrete equal to $100-150 \mathrm{kgf} / \mathrm{cm}^{2}$, produced from aerated concrete after 2 hours after filling, was reached only 12-14 hours after production.

Researches have shown that increasing of plastic strength of row foam concrete may be reached either by applying sulfate-containing component, that includes dehydrated hemihydrate gypsum, or by increasing temperature of foam concrete mass and hardening temperature up to $35-40^{\circ} \mathrm{C}$.

The results of laboratory research and development of compounds of non-autoclaved aerated concrete on the basis of ash and gypsum-containing components have been tested in a production environment by issuing of pilot batch of small wall blocks in the production line of the experimental workshop of the StroyindustryM LLP in Zheleznodorozhny city in Moscow oblast.

For production of aerated concrete were used as follows: Portland cement M400 - of Mikhailovsky plant, boiler fly ash of Ryazan TPP and grinded to a specific surface of $2500 \mathrm{~cm}^{2} / \mathrm{g}$ of natural gypsum.

Parameters of mixture preparation and characteristics of its properties are given in Table 2.

12 hours after manufacturing (in case of plastic strength equal to 500-600 $\mathrm{gf} / \mathrm{cm} 2$ ) blocks were steamed in a steaming chamber at the mode of $3+8+$ natural cooling, when the holding temperature is equal to $85 \pm 5^{\circ} \mathrm{C}$.

Further hardening of blocks occurred in the normal temperature and humidity conditions within 12-18 months.

In order to determine the basic physical and mechanical properties of aerated concrete, the samples were sawn out of experimental blocks.

Research of freeze resistance of produced aerated concrete of optimal compositions has shown that this material has a sufficient resistance at alternate freeze-thaw. Coefficient of freeze resistance after 50 cycles of alternate freezing and thawing is equal to 0.86 , loss of strength does not exceed $15 \%$ and meets the requirements of GOST 25485-89.

The aerated concrete produced on the basis of ash gypsum cement binding material comply, with respect to shrinkable deformations, with requirements of normative documents for non-autoclaved aerated concrete, at that a maximum value of shrinkage deformation is equal to $2.3 \mathrm{~mm} / \mathrm{m}$.

Coefficient of thermal conductivity ranges is fluctuating between $0.17-0.24 \mathrm{~W} / \mathrm{m}^{20} \mathrm{C}$ depending on the density and type of aerated concrete. It was found that the foam ash gypsum cement have lower thermal conductivity as compared with aerated ash gypsum concrete of the same composition and density.

Physical and mechanical properties of aerated concrete of optimal compositions

\begin{tabular}{|c|c|c|c|c|c|c|c|c|c|c|c|c|c|c|}
\hline \multirow[b]{2}{*}{ Moldings } & \multicolumn{5}{|c|}{ Consumption of Materials, $\mathrm{kg} / \mathrm{m}^{3}$} & \multicolumn{3}{|c|}{$\begin{array}{c}\text { Characteristics of } \\
\text { the Mixture }\end{array}$} & \multicolumn{6}{|c|}{ Indexes of Physical and Mechanical Properties } \\
\hline & Sinding & $\begin{array}{l}\text { Including } \\
\text { Cement }\end{array}$ & Ash & $\begin{array}{l}\text { Aluminum } \\
\text { Powder }\end{array}$ & Wate & W/S & \begin{tabular}{|c|} 
Fluidity \\
of \\
Mixture, \\
$\mathrm{cm}$
\end{tabular} & $\begin{array}{c}\text { Mixture } \\
\text { temperature, } \\
{ }^{\circ} \mathrm{C}\end{array}$ & $\begin{array}{c}\text { Dry } \\
\text { Density, } \\
\mathrm{kg} / \mathrm{m} 3\end{array}$ & $\left|\begin{array}{c}\text { Strength } \\
\text { after 28- } \\
\text { Days, } \\
\text { kgf / m3 }\end{array}\right|$ & $\begin{array}{l}\text { Rprop. } \\
\text { in } \% \\
\text { from } \\
\mathrm{R}_{28}\end{array}$ & $\begin{array}{c}\text { Thermal } \\
\text { Conductivity } \\
\mathrm{W} / \mathrm{m}^{\circ} \mathrm{C}\end{array}$ & $\begin{array}{c}\text { Freeze } \\
\text { Resistance, } \\
\text { Cycle }\end{array}$ & $\begin{array}{c}\text { Shrinkable } \\
\text { Deformations } \\
\mathrm{mm} / \mathrm{m}\end{array}$ \\
\hline 1 & 418 & 125 & 309 & 0.55 & 371 & 0.51 & 42 & 35 & 780 & 53 & 80.4 & 0.220 & $>50$ & 2.00 \\
\hline 2 & 418 & 125 & 309 & 0.55 & 371 & 0.51 & 41 & 34 & 810 & 57 & 82.5 & 0.219 & $>50$ & 2.10 \\
\hline 3 & 418 & 125 & 309 & 0.55 & 371 & 0.51 & 40 & 36 & 800 & 55 & 81.1 & 0.217 & $>50$ & 2.04 \\
\hline
\end{tabular}

According to its physical and mechanical properties of non-autoclaved aerated concrete on the basis of binding material with ash and gypsum-containing components, totally meet the requirements of regulations and close to certain characteristics (strength, freeze resistance) for autoclaved aerated concrete. 
It is reasonable to use produced non-autoclaved aerated concrete in the production of small wall blocks for the construction of low-rise residential and other buildings.

The calculation showed that the manufacturing prime cost of small wall blocks made of non-autoclaved aerated concrete based on fly ash and natural gypsum at 36\% less, but on the basis of ash and phosphogypsum at $40 \%$ less than manufacturing-represented blocks of non-autoclaved aerated concrete with cement and sand.

\section{References}

Used bibliography: V.V. Balyasnikov foam concrete on modified synthetic foam agents. Dissertation abstract of PhD in Technical Sciences: 05.23.05. - Belgorod, 2003. - $19 \mathrm{r}$.

V.V. Kondratyev Structure and process basis of superlight foam concrete production. Dissertation abstract of PhD in Technical Sciences: 05.23.05. - Kazan, 2003. - 21 r.

Aerated concrete with reduced volume weight ./ Under edit. Of A.T. Baranov and V.V. Makarichev - M.: Stroyistat, 1974.- $118 \mathrm{r}$.

A.P. Merkin Scientific and practical basis of improvement of structure and properties of porous concrete: Dissert. PhD in Technical Sciences. - M., 1971. $-270 \mathrm{r}$.

L.D. Shakhova V.V. Balyasnikov Foam agents for aerated concrete - Belgorod, 2002. - $147 \mathrm{r}$. 